\title{
PO RAZ KOLEJNY O KOMPETENCJACH INFORMACYJNYCH I POTRZEBIE ICH KSZTAŁTOWANIA
}

Rozważania na temat książki Ewy Jadwigi Kurkowskiej pt. Edukacja informacyjna w bibliotekach a rozwój społeczeństwa wiedzy (Warszawa: Wydaw. SBP, 2012).

Książka Ewy Jadwigi Kurkowskiej jest kolejną publikacją przygotowana przez Wydawnictwo SBP w ramach serii Nauka - Dydaktyka - Praktyka, poświęconą informacyjnej alfabetyzacji. Autorka zagadnienie Information Literacy (IL) przedstawia jako powinność bibliotek i bibliotekarzy wobec tworzącego się społeczeństwa wiedzy. Inne podejście do kompetencji informacyjnych reprezentuje Renata Piotrowska, kładąc nacisk na ich znaczenie w procesie edukacji szkolnej i analizując w kontekście zapisów Podstawy programowej kształcenia ogólnego [5]. Natomiast Justyna Jasiewicz opisuje zachowania informacyjne i ich związek z posiadana przez pokolenie Google wiedzą i umiejętnościami w zakresie posługiwania się informacja [3]. Na Information Literacy jako etap konieczny w kształtowaniu kultury informacyjnej młodych ludzi wskazuje pisząca tę recenzję, akcentując rolę biblioteki szkolnej w jej rozwoju [2]. Z innych pozycji na ten temat, chociaż nie wydanych przez SBP, na uwagę zasługuje książka Marioli Antczak traktująca o udziale bibliotek i bibliotekarzy szkolnych w procesie kształcenia społeczeństwa informacyjnego, ze szczególnym uwzględnieniem zagadnień edukacji informacyjnej i kompetencji informacyjnych nauczycieli [1].

Pozycje te świadczą o tym, że poruszana tematyka jest aktualna i wymaga pilnych rozwiązań w obszarze edukacji szkolnej, a także kształcenia dojrzałości informacyjnej ludzi dorosłych. Wymaga także interdyscyplinarnego podejścia do rozwiązywania problemów zarówno o charakterze teoretycznym, jak i prakseologicznym. Recenzowana książka mieści się w obszarze zainteresowań nauki o informacji, wpisując się w problematykę działalności informacyjnej bibliotek i ich pracy dydaktycznej z użytkownikami informacji w erze cyfrowej.

Autorka podjęła trud uporządkowania podstawowych zagadnień związanych z Information Literacy dotyczących głównie różnorodności w definiowaniu kluczowego dla książki pojęcia, kształcenia kompetencji informacyjnych, standardów IL, organizacji bibliotekarskich zajmujących się praktyką i badaniami nad IL. Dzięki dokonanej systematyce lektura tekstów na ten temat została ułatwiona, także poprzez wskazanie podstawowych źródeł dokumentalnych i instytucjonalnych umożliwiających analizę prezentowanych zagadnień. Dzięki takiej strukturze książkę można polecić przede wszystkim studentom kierunku informacja naukowa i bibliotekoznawstwo jako niezbędny podręcznik z zakresu współczesnych zadań edukacyjnych bibliotek. Jest to też książka dla osób zajmujących się problematyką kompetencji informacyjnych reprezentujących różne dyscypliny wiedzy, uzmysławiająca ogrom wysiłku włożonego przez bi- 
bliotekarzy w ukonstytuowanie się idei IL w świecie. Wartość książki polega na wskazaniu środowisku bibliotekarskiemu dominującej koncepcji odnoszącej się do edukacji informacyjnej i obowiązku jej realizacji, ale też na uświadomieniu pozostałym środowiskom konieczności podjęcia działań w obszarze polityki informacyjnej związanych z określeniem roli bibliotek i bibliotekarzy w rozwoju społeczeństwa wiedzy oraz ich dotychczasowych zasług na tym polu.

Autorka książki celnie zauważa, powołując się na przemyślenia Ralfa Dahrendorfa, niemiecko- brytyjskiego socjologa, politologa i polityka, że uczestnictwo w życiu społecznym możliwe jest, gdy członkowie społeczeństwa posiadają odpowiednie wykształcenie, by korzystać ze zdobyczy cywilizacyjnych i możliwości współuczestnictwa w strukturach demokratycznych [4, s. 55]. Stopień wykształcenia obywateli wpływa bowiem na uczestnictwo w życiu społecznym i stopień włączenia lub wykluczenia z różnych sfer jego aktywności. Równocześnie jednak istnieje niebezpieczeństwo, że pomimo postępującej demokratyzacji i powszechności edukacji, jest ona dostępna tylko do pewnego poziomu kształcenia $[4$, s. 49, 55]. Dlatego nauka i wiedza przeznaczona dla wybrańców nie przynosi korzyści wszystkim ludziom, lecz staje się przywilejem niewielkiej grupy dobrze wykształconych jednostek. Edukacja w społeczeństwie wiedzy, jak konkluduje autorka, musi być nastawiona na przekazywanie wiedzy ogólnej i kształtowanie postaw umożliwiających funkcjonowanie we współczesnym świecie przesyconym informacją. Toteż wiąże się ją z promowaniem umiejętności interdyscyplinarnych, wiedza ogólna stanowi bowiem punkt wyjścia do dalszego rozwoju [4, s. 63]. Nieodzownym komponentem jest wiedza o zarządzaniu informacja i wykorzystywaniu jej w procesie uczenia i samokształcenia. Proces kształcenia się i doskonalenia nie jest możliwy bez posiadania odpowiednich kompetencji informacyjnych, a te, jak pisze Kurkowska, nie sa wrodzone i „trzeba je stworzyć w procesie kształcenia" [4, s. 75]. Dlatego treści z tego zakresu muszą znaleźć się w programach nauczania na wszystkich poziomach i nie tylko uwzględniać wybrane elementy edukacji informacyjnej [4, s. 80], ale całokształt problemów zwiazanych z:

- uczestniczeniem w procesie informacyjnym (określanie i formułowanie potrzeby informacyjnej, selekcja źródeł informacji, tworzenie strategii wyszukiwania informacji w wyselekcjonowanych źródłach informacji, selekcja i gromadzenie wyszukanych informacji, ocena jakości zgromadzonych informacji, opracowanie i wykorzystanie zgromadzonych informacji, udostępnianie przetworzonej informacji i wiedzy),

- aspektem kulturowym (obejmującym rozwój świadomości informacyjnej, budowanie systemu wartości i wychowanie zgodne z etyką korzystania z informacji, kształtowanie pozytywnych postaw wobec informacji i wiedzy, kształtowanie pozytywnych zachowań użytkowników oraz rozwój ich kultury osobistej),

- funkcjonowaniem w różnych obszarach kultury informacyjnej (rozwój umiejętności samokształceniowych, kompetencji medialnych, kompetencji komunikacyjnych, kompetencji czytelniczych, umiejętności technicznych związanych z wykorzystaniem narzędzi informacyjnych) [2, s. 105-110].

Edukacja informacyjna musi zatem uwzględniać także kształtowanie kultury informacyjnej. Elementy tej kultury w Podstawie programowej kształcenia ogólnego oraz w wybranych podręcznikach szkolnych zanalizowała i przedsta- 
wiła w tabelach Hanna Batorowska [2, s. 112, 114, 118, 123, 135], a na bazie tego samego schematu analizę wymienionych elementów, ale występujących w standardach IL, zilustrowała Justyna Jasiewicz [3, s. 138-139].

Tak szeroki obszar kształcenia w zakresie IL traktowanej jako filozofia życia, a właściwie w zakresie kultury informacyjnej, związany jest z koniecznościa prowadzenia procesu dydaktyczno-wychowawczego zgodnie z zasadą zrównoważenia celów kulturowych i technologicznych odnoszących się nie tylko do edukacji informatycznej. Do tej pory większość autorów publikacji wydanych przez SBP koncentrowała uwagę na narzędziach omawianego problemu i ten aspekt został opracowany w sposób wyczerpujący. Analiza podstaw programowych, programów, podręczników, dokumentów prezentujących politykę informacyjna, standardów, wytycznych, raportów, opisów działań organizacji, stowarzyszeń i innych instytucji zajmujących się IL, projektów przez nie podejmowanych, lansowanych modeli kształcenia zdaje się wyczerpywać listę zagadnień związanych z Information Literacy, chociaż wciąż można prowadzić bardziej dogłębne badania. To samo dotyczy treści wprowadzających w problematykę społeczeństwa informacyjnego lub społeczeństwa wiedzy i opierania rangi tych dwóch formacji na piramidzie rozwoju wiedzy, w której od danych przechodzi się do informacji, następnie do wiedzy, by osiagnąć na jej szczycie stan mądrości. Skoro o zarządzaniu informacją i zarządzaniu wiedza wiemy już tyle, celowym byłoby podjąć rozważania na temat „zarządzania mądrościa”".

W książce Ewy Jadwigi Kurkowskiej poruszona została ważna kwestia konieczności uznania wagi edukacji informacyjnej w tworzącym się społeczeństwie wiedzy i traktowania jej za równie kluczowy cel polityki edukacyjnej jak kształcenie permanentne czy rozwój kompetencji samokształceniowych. Autorka słusznie stwierdza, że w nowoczesnym społeczeństwie szkoła powinna kształtować kreatywne postawy młodzieży, a nie tylko wyposażać uczniów w umiejętności narzędziowe. Nawiązuje także do pojęcia społeczeństwa kreatywnego jako kolejnego stadium rozwoju społeczeństwa wiedzy i wskazuje na nieodzowność kształtowania w procesie edukacji kreatywnych postaw młodzieży. Równocześnie podziela watpliwości sformułowane przez autorów Raportu Klubu Rzymskiego w 1979 r. (raport Uczyć się - bez granic: jak zewrzeć „lukę ludzką"), że trudno nauczyć kreatywności, ponieważ jest to cecha indywidualistów i innowatorów, a zunifikowane systemy edukacji nie zawsze dają szansę wykazania się takim ludziom. Należy jednak dążyć do stworzenia optymalnych warunków sprzyjających ujawnianiu się i rozwijaniu tych cech u ludzi młodych [4, s. 58, 59].

Książka została podzielona na pięć części. W części pierwszej, wprowadzającej w problematykę społeczeństwa wiedzy, poruszono zagadnienie różnic pomiędzy nim a społeczeństwem informacyjnym oraz kontekst technologiczny, a także aspekt dotyczący gospodarki i kształtowania postaw demokratycznych. W rozdziale drugim omówiono podstawowe trendy we współczesnej edukacji, zwracając uwagę na takie jej elementy jak: kształcenie ustawiczne, e-learning, samokształcenie i edukację informacyjną. W trzeciej części autorka przedstawia definicje Information Literacy, porównuje koncepcje Christiny Doyle, Christiny Susan Bruce, Sheilię Webber i Billa Johnstona, stwierdzając w konkluzji, że 
Information Literacy trzeba wiązać z kompetencjami informacyjnymi kształtowanymi w procesie edukacji informacyjnej [4, s.118].

W kolejnej części pracy omówiono działalność międzynarodowych i zagranicznych organizacji bibliotekarskich na rzecz kształtowania kompetencji informacyjnych, zakres prowadzonych prac oraz wydawane publikacje poświęcone tej tematyce. Organizacje te to:

- organizacje o charakterze międzynarodowym: IFLA (Międzynarodowa Federacja Stowarzyszeń i Instytucji Bibliotekarskich), IASL (Międzynarodowe Stowarzyszenie Bibliotekarstwa Szkolnego), IIL (Instytut Edukacji Informacyjnej), EnIL (Europejska Sieć ds. Edukacji Informacyjnej), UNESCO (Organizacja Narodów Zjednoczonych do Spraw Oświaty, Nauki i Kultury), IAIL (Międzynarodowa Organizacja Alfabetyzacji Informacyjnej),

- organizacje amerykańskie: ALA (Stowarzyszenie Bibliotek Amerykańskich), ACRL (Stowarzyszenie Bibliotek Akademickich i Naukowych), AASL (Amerykańskie Stowarzyszenie Bibliotekarzy Szkolnych), NFIL (Narodowe Forum ds. Edukacji Informacyjnej),

- organizacje australijskie: ALIA (Australijskie Stowarzyszenie Bibliotek i Informacji), CAUL (Rada Bibliotekarzy Uniwersytetów w Australii), ANZIIL (Instytut Alfabetyzacji Informacyjnej Australii i Nowej Zelandii),

- organizacje angielskie: SCONUL (Stowarzyszenie Bibliotek Narodowych i Akademickich), CILIP (Instytut Profesjonalistów z Zakresu Informacji i Bibliotekarstwa).

Omówiono także działalność Komisji ds. Edukacji Informacyjnej SBP (Stowarzyszenia Bibliotekarzy Polskich).

Dobór dokonany przez autorkę wskazuje, że preferowała organizacje amerykańskie, australijskie i angielskie, zapewne dlatego, że idea IL zrodziła się w tych krajach, a ich środowiska bibliotekarskie wypracowały podstawy teoretyczne i wzorcowe modele kształcenia kompetencji informacyjnych. Stamtąd też pochodza pierwsze standardy w zakresie IL i przykłady dobrych praktyk naśladowane i wdrażane na całym świecie. Aby przedstawić zjawisko IL w pełnej perspektywie, należałoby dokonać krytycznego oglądu działań organizacji bibliotekarskich zajmujących się omawiana problematyką w ujęciu ogólnoświatowym.

Zakres kształcenia kompetencji informacyjnych odzwierciedlaja standardy Information Literacy. W ostatniej części książki autorka omawia najważniejsze normy i modele obowiązujące w edukacji informacyjnej na świecie, wypracowane przez teoretyków i praktyków z USA, Wielkiej Brytanii, Australii, Nowej Zelandii, Austrii, Niemiec i Czech. W Polsce środowisko bibliotekarskie nie wypracowało wspólnych standardów dotyczących kształtowania kompetencji informacyjnych, dlatego autorka odwołuje się jedynie do inicjatywy bibliotek uczelni medycznych [4, s. 182].

Jedną z pierwszych prób nawiązania współpracy w zakresie Information Literacy pomiędzy bibliotekarzami reprezentującymi różnego typu biblioteki z całej Polski była międzynarodowa konferencja Edukacja Informacyjna i Medialna. Archipelagi wiedzy (EIM), która odbyła się w dniach 4-5 października 2012 r. w Bibliotece Uniwersyteckiej w Warszawie. Organizatorami EIM była Komisja ds. Edukacji Informacyjnej (KEI) Zarządu Głównego SBP oraz Biblioteka Uniwersytecka w Warszawie. Tematyka konferencji potwierdziła aktualność 
i potrzebę wypracowania praktycznych wskazówek na temat realizacji edukacji informacyjnej, ram systemowych dla kształcenia kompetencji informacyjnych, a także metod i technik pracy z użytkownikami informacji. Zorganizowanie konferencji przez KEI SBP, której misja jest popularyzowanie edukacji informacyjnej i wykorzystywanych w tej edukacji metod rozwijających umiejętności skutecznego poszukiwania i efektywnego wykorzystywania informacji oraz podejmowane przez tę Komisję działania, daje nadzieję na konsolidację polskiego środowiska bibliotekarskiego w tym obszarze i włączenie się do projektów międzynarodowych.

Książka Ewy Jadwigi Kurkowskiej oraz inne pozycje wymienione w recenzji przyczyniają się do uświadomienia wagi tej edukacji osobom odpowiedzialnym za przygotowanie młodzieży do funkcjonowania w świecie współczesnych technologii informacyjno-komunikacyjnych i mediów elektronicznych.

\section{Literatura}

1. Antczak M.: Rola bibliotek i bibliotekarzy szkolnych w edukacji społeczeństwa informacyjnego na tle przeobrażeń oświatowych w Polsce w latach 1989-2007. Łódź: Wydaw. Uniwersytetu Łódzkiego. 2010.

2. Batorowska H.: Kultura informacyjna w perspektywie zmian w edukacji. Warszawa: Wydaw. SBP. Nauka - Dydaktyka - Praktyka nr 117, 2009.

3. Jasiewicz J.: Kompetencje informacyjne młodzieży. Analiza - stan faktyczny - kształcenie na przykładzie Polski, Niemiec i Wielkiej Brytanii. Warszawa: Wydaw. SBP. Nauka - Dydaktyka - Praktyka nr 138, 2012.

4. Kurkowska E. J.: Edukacja informacyjna w bibliotekach a rozwój społeczeństwa wiedzy. Warszawa: Wydaw. SBP. Nauka - Dydaktyka - Praktyka nr 137, 2012.

5. Piotrowska R.: Edukacja informacyjna w polskiej szkole. Warszawa: Wydaw. SBP. Nauka - Dydaktyka - Praktyka nr 123, 2011. 